\title{
Effects of Effluents From Gbalegbe River, Delta State, Nigeria On The Breeding Performance Of Clarias Gariepinus (Burchell, 1822)
}

\author{
Ewutanure, Somorhire Jacob \\ Department of Fisheries and Aquaculture Management \\ Faculty of Marine Environmental Management, Nigeria Maritime University \\ Okorenkoko, Warri South, Delta State, Nigeria. \\ E-mail: ewutanure@gmail.com \\ Phones: +2348101634482. \\ Olaifa, Flora Eyibio \\ Department of Aquaculture and Fisheries Management \\ Faculty of Renewable Natural Resources \\ University of Ibadan, Ibadan, Nigeria. \\ Emails: floraolaifa@yahoo.com \\ Phones: +2348035509342.
}

\section{Member Proceedings Citation Format}

Ewutanure, S.J. \& Olaife, F.E. (2021): Effects Of Effluents From Gbalegbe River, Delta State, Nigeria On The Breeding Performance Of Clarias Gariepinus (Burchell, 1822). Proceedings of the Accra Bespoke Multidisciplinary Innovations Conference. University of Ghana/Academic City University College, Accra, Ghana. December 2021. Pp 163-178 www.isteams.net/ghanabespoke2021. DOI https://doi.org/ 10.22624/AIMS/ABMIC2021P13 


\title{
Effects Of Effluents From Gbalegbe River, Delta State, Nigeria On The Breeding Performance Of Clarias Gariepinus (Burchell, 1822)
}

\author{
Ewutanure, Somorhire Jacob \& Olaifa, Flora Eyibio
}

\begin{abstract}
A study was carried out on Gbalegbe River water to assess the impact of anthropogenic activities on the breeding and growth performance of Clarias gariepinus using effluent directly from the point source. The experiment was set - up in a complete randomised design with 5 treatments (TR1, TR2, TR3, TR4 and TR5) and 2 replicates for 12 weeks. Concentrations of $100 \%, 75 \%$, $50 \%, 25 \%$ and $0 \%$ were prepared according to standard methods. Borehole water was used as control $(0 \%)$ after exposure for 72 hours. Two matured gravid and one male $\mathrm{C}$. gariepinus of $4.5 \mathrm{~kg}^{-1}$ each were purchased from a reputable fish farm in Delta State, Nigeria and acclimatised in the laboratory for 2 weeks. The two gravid C. gariepinus were then induced with Ovaprim hormone at $0.5 \mathrm{mg}$. $\mathrm{kg}^{-1}$. Stripping was done after a latency period of 9 hours. The eggs were then fertilized with the milt obtained from the male fish at a temperature of $24.5{ }^{\circ} \mathrm{C}$. About 1.0 $g$ of eggs was incubated in ten aquaria of water holding capacity of 20 litres each. Hatching started and stopped at 20 and 28 hours, respectively. Fish were fed ad-libitum for 84 days while unhatched eggs, unconsumed feed and dead fry were carefully siphoned. Parameters analysed were water quality: Temperature $-{ }^{\circ} \mathrm{C}$, Dissolved Oxygen, DO - mg..-1); Growth (\% Hatchability and Feed Conversion Ratio - FCR); Total Petroleum Hydrocarbon (TPH) in water (mg.L-1) and Heavy Metals (HM) - (Copper, Chromium - mg. $\left.\mathrm{L}^{-1}\right)$ in fish (mg.kg-1), Packed Cell Volume (\% PCV) and Alkaline Phosphatase (ALP - IU.L-1). The duration of the experiment was 12 weeks. Data obtained were subjected to inferential and descriptive statistics at $\alpha_{0.05}$. Highest $(27.50 \pm 0.55)$ and least (24.53 \pm 4.35$)$ Temperature; DO (4.53 $\pm 0.15,3.01 \pm 1.65)$; Hatchability $71.13 \pm 0.37$, 39.74 \pm 2.06$)$; FCR $(1.19 \pm 0.43,3.92 \pm 0.08)$ were obtained in TRT5 and TR1, respectively. Highest $(0.67 \pm 0.03)$ and least $(0.09 \pm 0.02) \mathrm{TPH}$ in: water occurred in TRT1 and TRT4; C. gariepinus $(5.01 \pm 0.66,0.18 \pm 0.07)$ in TRT1 and TRT4, respectively. Highest $(0.66 \pm 0.53)$ and least $(0.09 \pm 0.00) \mathrm{HM}$ (Chromium and Nickel) in water where recorded in TRT1 and TRT2. HM Copper and Manganese in C. gariepinus ranged from $0.04 \pm 0.01$ to $0.64 \pm 0.13$ in TRT4 and TRT1. Highest $(49.37 \pm 3.07)$ and least $(20.62 \pm 3.37)$ PCV occurred in TRT5 and TRT1; ALP $(32.22 \pm 3.18,6.99 \pm 4.26)$ in TRT1 and TRT5, respectively. The sharp variation in FCR, HM and ALP showed that the increased anthropogenic effluents in Gbalegbe River could threaten the positive breeding performance of $\mathrm{C}$. gariepinus. It is therefore recommended that consistent and adequate monitoring of Gbalegbe River should be encouraged to guarantee sustainable fisheries abundance.
\end{abstract}

Keywords: Anthropogenic Activities, Fish Breeding, Feed Conversion Ratio, Heavy Metals, Packed Cell Volume.

\section{INTRODUCTION}

The rapid increase of aquatic pollutants and the extent of exploitation of the aquatic resources for glass, oil production and thermal industries to meet the demand of the increasing human populace drastically reduce the aesthetic values and supportive capacity of water bodies for biota (Ewutanure and Olaifa, 2018a; Bukola et al. 2015). This therefore, places stress on the aquatic flora and fauna communities (Subhendu 2000). 
While some pollutants decomposed, others form insoluble salts that precipitate and bind with sediment (Abel and Afolab 2007). Bioaccumulation of toxicants in fish could cause damage to liver, kidney and other internal organs (Ewutanure and Olaifa, 2018b; Olawusi - Peters et al. 2014). Many aquatic organisms are known to bio-accumulate toxicants from their environment without any obvious physical abnormality (Edokpayi and Nwoji 2000). These toxicants are biomagnified in predators at very high concentrations (Bukola et al. 2015).

The increased anthropogenic loads in inland water portend potential risk to aquatic biota (Ewutanure and Olaifa, 2018c; Akintola et al. 2009). Negative impacts of pollution have been detected in populations of various organisms inhabiting different aquatic ecosystems and their breeding performance (Abel 2009). None existence of some commercially importance fish species is one of the major changes recorded in inland water because of pollution (Valipour et al. 2012).

It has been established that biochemical, cellular and tissue modifications observed in fish are due to series of changes in the aquatic habitats due to chemical contaminants (Ewutanure and Olaifa, 2018; Nwoji et al. 2010). Improper management of wastes generated by various anthropogenic activities is a major problem in the developing countries (Valipour 2013a). This can be ascribed to the unsafe disposal of industrial effluents into the environment with deleterious effects on lentic water which often rendered it unsuitable for primary productivity and other human uses (Ewutanure and Olaifa, 2021; Valipour 2013b).

According to Ewutanure and Olaifa, (2018c) Gbalegbe River has in recent times, continued to received effluents from sand extraction, rubber, glass, power plant and oil industries as well as untreated sewage from within and around it. This study therefore aims at evaluating the effects of effluents from anthropogenic activities in Gbalegbe River on the breeding performance of Clarias gariepinus.

\section{MATERIALS AND METHODS}

A matured male and two gravid females of C. gariepinus both of average weight of $4.50 \mathrm{~kg}$ and 2 years old were purchased from a recognised fish Farm in Olomoro, Delta State, Nigeria. The fish were differentiated by observing their genital papillae (Achionye - Nzeh and Israel 2012). Eggs oozed out directly at a slight pressure on the stomach of the gravid females. The broodstock were conditioned for two weeks to allow them get used to the new environment. The females were intramuscularly injected using ovaprim hormone at the recommended rate of 0.5 mg.kg-1 body weight (Omeje et al. 2013). The injected fish were kept in two separate 50 litres gallons for a latency period of 9 hours at a temperature of $27.50 \circ \mathrm{C}$.

Stripping was done after the latency period while the testes of the male were harvested to obtain the milt. A $100 \mathrm{~mL}$ of $0.9 \%$ physiological saline was added to increase the volume of the milt before fertilizing the eggs with it. The eggs together with the milt were properly and carefully stirred in a plastic bowl using a plastic spoon to improve fertilization. The experiment was carried out in a complete randomised design (CRD) with five treatments and two replicates for 12 weeks. The effluent used was collected directly from a major point source into Gbalegbe River. Borehole water was used as control after exposure to atmospheric re - aeration for 72 hours to improve its oxygen level. 
Food and Agricultural Organisation, FAO (2009) reported that $1.00 \mathrm{~g}$ of fish eggs contained 700 eggs while Omeje et al., (2013) reported that $1.00 \mathrm{~g}$ of eggs contained 750 eggs but in this study, 1.00g of fish eggs was found to contained 685 eggs. After fertilization, $1.00 \mathrm{~g}$ of eggs each was weighed and incubated in each of the five treatments with kakaban carefully arranged at their bottom. Each aquarium tank had a dimension of $44.40 \times 25.20 \times 29.50 \mathrm{~cm}$ and water holding capacity of 20 litres. Each treatment has its own concentration for the bioassay as 100 $\%, 75 \%, 50 \%, 25 \%$ and $0 \%$ (control) respectively.

Hatching started at 20 hours and stopped at 28 hours after incubation at a temperature of $26.50^{\circ} \mathrm{C}$. The unhatched eggs and dead hatchlings were carefully siphoned out and counted to determine percentage hatchability, while feeding was done after the third day. Throughout the remaining 81 days, the fish were fed ad libitum with locally formulated feed, dead fish and unconsumed feed were carefully siphoned out while the numbers of dead fish were counted to determine percentage survival. Growth parameters recorded during the 12 weeks bioassay using the water from the most polluted station were:

$\%$ Hatchability $=\frac{\text { Total number of hatched eggs }}{\text { Total number of eggs incubated }} \times 100 \%$

Initial mean weight $=\frac{\text { Total weight of fish }}{\text { Total number of fish }}$

Mean bi - weekly weight gain $=\frac{\text { Total bi-weekly weight gain }}{\text { Total surviving fish weight }}$

Absolute growth rate $(\mathrm{g} /$ day $)=\frac{\text { Final weight gain-Initial weight }}{\text { Culture period (days) }}$

Specific growth rate $=\frac{\text { Logefinal weight }- \text { Log initial weight }}{\text { Culture periods (days) }} \times 100 \%$

$\%$ Survival $=\frac{\text { Number of survival after culture }}{\text { Total number of fish stocked }} \times 100 \%$
(Zeiotoun et al. 1973)

(Ishwata, 1969)

(Ishwata, 1969)

(Lazo et al. 1998)

(Brown, 1957)

Mean size of at harvest $=\frac{\text { Total weight of fish at the end of culture period }}{\text { Total number of fish harvested at the end of culture period }}$ (Ishwata, 1969)

Feed conversion ratio $=\frac{\text { Quantity of feed fed }}{\text { Weight gain }}$

(Lazo et al. 1998)

$\%$ Feed efficiency $=\frac{1}{\text { Feed conversion ratio }} \times 100 \%$

Fish yield $=\frac{\text { Weight of fish }(\mathrm{Kg}) / \mathrm{m} 2}{\text { Culture period }}$

(Fleck, 1976)

\section{Collection of blood Samples}

The fish were placed belly upwards and blood sample obtained from the anal circulation with the aid of heparinized $5 \mathrm{~mL}$ disposable plastic syringes and a 21gauge disposable hypodermic needle. The site chosen for puncture ( $3-4 \mathrm{~cm}$ from the genital opening) was wiped dry with tissue paper to avoid contamination with mucus. The needle was inserted perpendicularly to the vertebral column and gently aspirated during penetration. It was then pushed gently down until blood started to enter as the needle puncture a caudal blood vessel. 
Blood was taken under gentle aspiration until about $2 \mathrm{ml}$ have been obtained. The needle was then withdrawn and gently emptied into lithium heparin anticoagulant and plain tubes respectively. Thereafter, the blood samples were packed in iced chip and transported to the laboratory for further analyses (Erfan et al. 2015)

Pack cell volume (PCV)

The blood samples were introduced into capillary tubes, placed in a centrifuge (Model: SH 120 - 1) set at $11000 \mathrm{rpm}$ and centrifuged for 5 minutes to separate the serum from the blood. The blood concentrates (sediments) at the bottom of the capillary tubes. After centrifuging, the capillary tubes were transferred into the Hawksley micro-Haematocrit reader where the PCV were read off (Ejraei et al. 2015).

White blood cells (WBC)

The blood samples were dispensed into the test tubes containing avian fluid with the aid of an automated pipet. The avian fluid was used because the morphology of the cells of fish, rabbits and birds are similar. About $0.5 \mathrm{~mL}$ of blood sample was measured with the aid of WBC pipette, the pipette was filled to mark with WBC fluid, the solution was dropped on neubauer improved chamber and covered with a slip, neubauer was set under the microscope using X 40 objective, the number of cells (WBC) were counted and multiplied by 50

\section{Blood Plasma}

Red blood cells were separated after PCV determination from the upper fluid (plasma). The plasma was then dispensed on a refractometer and the values recorded

Haemoglobin $(\mathrm{Hb})$

A $5 \mathrm{~mL}$ drasking $(\mathrm{Hb})$ solution was added into a test tube, 20 microliter $(20 \mu \mathrm{L})$ of blood sample was measured with the aid of haemocytometer pipette, added into the test tube and allowed to mix properly. Thereafter, the test tube was placed in a colorimeter at $520 \mathrm{~nm}$ to obtain $\mathrm{Hb}$ values.

\section{Red blood cells}

About $0.5 \mathrm{~mL}$ of blood sample was measured with the aid of RBC pipette. The pipette was filled to mark with RBC fluid. The solution was dropped on neubauer improved chamber and covered with a slip. Neubauer was set under the microscope using $X 40$ objective. The number of cells (RBC) were then counted and multiplied by 10,000

Determination of haematic indices of C. gariepinus

The following haematic indices (mean cell volume, mean cell haemoglobin, mean cell haemoglobin and mean cell haemoglobin concentration) were calculated by using the formulae stated below:

$$
\begin{array}{ll}
\mathrm{MCV}=\frac{\mathrm{PCV} \times 10}{\operatorname{RBC} \times 10^{6}} & (\text { fentolitre }) \\
\mathrm{MCH}=\frac{\operatorname{Hb} \times 10}{\operatorname{RBC} \times 10^{6}} & (\text { pictogram }) \\
M C H C=\frac{\mathrm{Hb}}{\mathrm{PCV} \times 10^{6}} \times 100 & (\mathrm{~g} / \mathrm{dL})
\end{array}
$$


Leucocytes differentials cells

Blood smears were made on the slides and air-dried. The air -dried slides were stained with Giemsa differential stains (Giemsa Laboratory Limited, Molbase, Shanghai). The slides were thereafter placed and viewed under electrical microscope (B - 350 - Optika, Italy) at a magnification of X1000. Each of the slides were rotated in one direction while the number of basophils, monocytes, neutrophils, eosinophils and lymphocytes were counted using blood cells differential counter (Durga, Miniscience, Inc., USA). The differential cells were expressed in percentage (Erfan et al. 2015).

Determination of serum biochemical indices of Clarias gariepinus from Gbalebge River Fresh blood samples were collected without anticoagulant very close to the anal fin. The needle was inserted just behind the anal fin in a dorsa-cranial direction till striking the vertebrate. The needle was gently drawn backward to allow blood to flow into the syringe. The collected blood sample was centrifuged at $11000 \mathrm{rpm}$ for 5 minutes to separate serum for serological (biochemical) analysis.

\section{Serum biochemistry of C. gariepinus from Gbalegbe River}

\section{Creatinine}

Creatinine was determined using Jaffe's spectrophotometric method (Pratt, 1996) described below:

Blood is drawn from C. gariepinus and transferred into a centrifuge tube;

- Serum was obtained by centrifugation of blood for 5 minutes at $11000 \mathrm{rpm}$;

- Calculated concentration of creatinine in the serum was done using the Jaffe's method as follows: In a clean dry test tube, $0.5 \mathrm{ml}$ distilled water was added (blank), then add $0.5 \mathrm{ml} \mathrm{NaOH}$ and $0.5 \mathrm{ml}$ picric acid. The content was mixed properly and allowed to stand for 15 minutes.

- The absorbance value was measured at $500 \mathrm{~nm}$.

Serum biochemical parameters such as glucose, sodium, plasma protein, albumin, globulin, alanine aminotransferase, alkaline phosphatase, potassium and aspartate aminotransferase and urea were determined using standard kit (Randox kit, United Kingdom).

\section{Statistical analyses}

Data from this study were subjected to descriptive and inferential statistics analysis using SPSS (version 20). Data were pooled and presented as spatial and temporal mean variances and compared by means of one - way ANOVA in order to evaluate if their differences were significant at $p<0.05$. 


\section{RESULTS}

The Physico - chemical parameters of water are presented in Table 1. Highest (4.85 \pm 1.98$)$ $\mathrm{mg} / \mathrm{L}$ and least $(2.36 \pm 1.04) \mathrm{mg} / \mathrm{L}$ DO were recorded in T5 and T1; $\mathrm{pH}(6.80 \pm 2.17,5.90 \pm 1.23)$ occurred in T5 and T3; Temperature $(28.50 \pm 5.20,25.50 \pm 0.75){ }^{\circ} \mathrm{C}$ were recorded in T1 and T2; Nitrate $(0.13 \pm 0.01,0.02 \pm 0.01)$ were obtained in T1 and T5; TSS $(46.39 \pm 7.69,23.13 \pm 4.16)$ $\mathrm{mg} / \mathrm{L}$ were obtained in T1 and T3; Alkalinity $(41.06 \pm 7.19,28.36 \pm 2.14) \mathrm{mg} / \mathrm{L}$ occurred in T1 and T2, respectively. The concentrations of water from Gbalegbe River and dilution water used for the induced breeding of $\mathrm{C}$. gariepinus for 84 days, compositions of ingredients used for the experimental feed formulation, proximate composition of the experimental diet, concentration of TPH in water and C. gariepinus, concentrations of heavy metals in water and C. gariepinus, basic growth parameters of Clarias gariepinus, haematological indices and serum biochemical profiles of Clarias gariepinus measured during the 84 days bioassay are shown in Tables 2, 3 , $4,5,6,7,8,9,10$ and 11, respectively. The histopathological results are shown in Plate 1.

Pollutants detected in experimental set up

Pollutants detected in water and fish were total petroleum hydrocarbon (TPH) and heavy metals (HM). Highest and least TPH in water were $0.67 \pm 0.03 \mathrm{mg} . \mathrm{L}^{-1}$ and $0.09 \pm 0.02{\mathrm{mg} . \mathrm{L}^{-1} \text { in TRT1 }}^{-1}$ week 2 and TRT4 week 4; C. gariepinus (5.01 $\pm 0.66,0.18 \pm 0.07) \mathrm{mg}^{-k^{-1}}{ }^{1}$ in TRT1 week 0 and TRT4 week 8 , respectively. Highest $(0.66 \pm 0.53) \mathrm{mg} . \mathrm{L}^{-1}$ and least $(0.09 \pm 0.00) \mathrm{mg} . \mathrm{L}^{-1} \mathrm{HM}$ in water were $\mathrm{Cr}$ in TRT1 and $\mathrm{Ni}$ in TRT 2; C. gariepinus $\mathrm{Cu}(0.64 \pm 0.13) \mathrm{mg}^{-k^{-1}}$ in TRT1 $^{-1}$ and Mn (0.04 \pm 0.01$)$ mg.kg-1 in TRT4 respectively.

Haematological parameters of C. gariepinus determined Highest (49.37 \pm 3.07$) \%$ and least $(20.62 \pm 3.37) \%$ PCV and $\mathrm{Hb}(13.61 \pm 8.27,4.31 \pm 0.98)$ g.dL 1 were recorded in TRT 5 and TRT1, RBC $(9.07 \pm 1.50,2.18 \pm 0.04) 10^{6} \mathrm{~mm}^{-3}$ occurred in TRT 5 and TRT 2, WBC $(10.22 \pm 1.72,2.12 \pm 1.24) 10^{3} \mathrm{~mm}^{-3}$, MCV $(6.33 \pm 0.61,2.16 \pm 1.19) \mathrm{fL}, \mathrm{MCH}$ (8.53 $\pm 1.74,1.12 \pm 1.67) \mathrm{Pg}, \mathrm{MCHC}(48.09 \pm 12.57,6.12 \pm 4.41)$ g.dL-1, Neut $(58.69 \pm 11.72$,

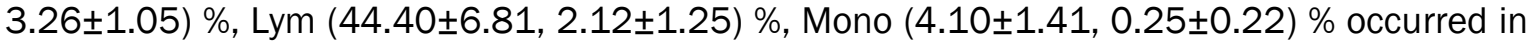
TRT 5 and TRT 1, Eos $(4.23 \pm 2.02,0.17 \pm 0.09) \%$ was obtained in TRT 5 and TRT 2, while Baso $(1.78 \pm 0.03,0.14 \pm 0.07) \%$ occurred in TRT 3 and TRT 5, respectively.

Biochemical profiles of $\mathrm{C}$. gariepinus measured

Highest (41.44 \pm 2.50$)$ g.dL-1 and least (16.77 \pm 5.98$)$ g.dL-1 glucose were obtained in TRT 1 and TRT 4, Urea (29.22 $\pm 6.77,6.50 \pm 2.12)$ g.dL-1 in TRT 1 and TRT 5; Na (53.45 $\pm 0.78,42.69 \pm 5.21)$ mg. $L^{-1}$ in TRT 3 and TRT 4; PP $(5.65 \pm 2.33,1.99 \pm 1.40)$ in TRT 1 and TRT 3; Albumin $(3.57 \pm 2.03$, 1.26 \pm 0.40$)$; Globulin (2.51 $\pm 0.71,0.83 \pm 0.22)$ in TRT1 and TRT5; Albumin-Globulin ratio $(2.70 \pm 0.21,1.42 \pm 0.11)$ in TRT 3 and TRT 1; ALP $(32.22 \pm 3.18,6.99 \pm 4.26)$ and ALT $(24.23 \pm 9.58,6.23 \pm 3.92)$ in TRT 1 and TRT 5; $\mathrm{K}(2.03 \pm 1.38,1.30 \pm 0.42)$ in TRT 2 and TRT 3; Creatinine $(38.50 \pm 24.75,3.38 \pm 0.54)$ and AST $(40.44 \pm 7.57,4.99 \pm 0.01)$ in TRT 1 and TRT 5 respectively.

Growth parameters of C. gariepinus monitored for the 12 weeks

Highest and lowest \% hatchability were 71.13 $\pm 0.37,39.74 \pm 2.06$; MBWG $(6.62 \pm 0.17$, $0.19 \pm 0.02)$ g, AGR $(18.74 \pm 0.04,4.22 \pm 0.01)$ g.day-1, SGR $(6.29 \pm 0.75,0.89 \pm 0.31) \%$; Suvivors $(63.33 \pm 1.45,34.17 \pm 8.09) \%$. AWaH $(37.05 \pm 2.79,13.92 \pm 8.27) \mathrm{g}$ and fish yield $(0.10 \pm 0.01$, $0.04 \pm 0.01)$ were recorded in TRT5 and TRT1, while highest $(3.92 \pm 0.08)$ and least $(1.19 \pm 0.43)$ FCR occurred in TRT 1 and TRT 5 respectively. 
Table 1. Physico-chemical parameters determined during the 12 weeks culture periods of Clarias gariepinus

\begin{tabular}{|c|c|c|c|c|c|c|c|}
\hline \multirow[b]{2}{*}{ Parameters } & \multicolumn{5}{|c|}{ Numbers of treatment } & \multirow[b]{2}{*}{ P-values } & \multirow[b]{2}{*}{$\begin{array}{l}\text { Boyd, } \\
\text { (1998) }\end{array}$} \\
\hline & 1 & 2 & 3 & 4 & 5 (Control) & & \\
\hline $\mathrm{DO}(\mathrm{mg} / \mathrm{L})$ & $2.36 \pm 1.04$ & $4.05 \pm 0.45$ & $3.01 \pm 0.75$ & $3.42 \pm 1.78$ & $4.85 \pm 1.98$ & $0.035 * *$ & $5-10$ \\
\hline $\mathrm{Ph}$ & $6.59 \pm 2.45$ & $6.50 \pm 1.56$ & $5.90 \pm 1.23$ & $6.70 \pm 1.34$ & $6.8 \pm 2.17$ & 0.098 & $6.5-8.5$ \\
\hline $\begin{array}{l}\text { Temperature } \\
{ }^{\circ} \mathrm{C}\end{array}$ & $28.50 \pm 5.2$ & $25.50 \pm 0.75$ & $28.50 \pm 0.71$ & $25.60 \pm 9.56$ & $27.50 \pm 5.93$ & 0.056 & $25-32$ \\
\hline $\begin{array}{l}\text { Nitrate }(\mathrm{mg} / \mathrm{L}- \\
\mathrm{N})\end{array}$ & $0.13 \pm 0.01$ & $0.09 \pm 0.02$ & $0.04 \pm 0.01$ & $0.03 \pm 0.01$ & $0.02 \pm 0.01$ & $0.045 * *$ & $0.1-3.0$ \\
\hline $\begin{array}{l}\text { Nirite }(\mathrm{mg} / \mathrm{L}- \\
\mathrm{N})\end{array}$ & $0.01 \pm 0.01$ & $0.01 \pm 0.01$ & $0.01 \pm 0.01$ & $0.03 \pm 0.01$ & $0.01 \pm 0.01$ & 0.081 & $0.0-0.5$ \\
\hline TSS (mg/L) & $46.39 \pm 7.69$ & $25.59 \pm 4.23$ & $23.13 \pm 4.16$ & $24.07 \pm 6.25$ & $31.42 \pm 18.46$ & $0.023 * *$ & $<500$ \\
\hline $\begin{array}{l}\text { Alkalinity } \\
\text { (mg/L) }\end{array}$ & $41.06 \pm 7.19$ & $28.36 \pm 2.14$ & $32.95 \pm 0.87$ & $38.12 \pm 14.49$ & $35.06 \pm 3.56$ & 0.091 & $50-300$ \\
\hline
\end{tabular}

Table 2. Concentrations of water from Gbalegbe River and dilution water used for the induced breeding of $\mathrm{C}$. gariepinus for 12 weeks days

\begin{tabular}{llll}
\hline Treatments & \% Concentration & Volume of diluting water $(\mathrm{L})$ & Volume of effluent $(\mathrm{L})$ \\
\hline 1 & 100 & 0.00 & 20.00 \\
2 & 75 & 5.00 & 15.00 \\
3 & 50 & 10.00 & 10.00 \\
4 & 25 & 15.00 & 5.00 \\
5 (Control) & 0 & 20.00 & 0.00 \\
\hline
\end{tabular}

Table 3. Compositions of ingredients used for the experimental feed formulation

\begin{tabular}{llllllll}
\hline Ingredients & DM (\%) & MC (\%) & CP (\%) & CF (\%) & EE (\%) & Ash (\%) & NFE (\%) \\
\hline GNC & 91.05 & 8.95 & 45.97 & 5.68 & 8.96 & 7.01 & 23.43 \\
FM & 78.13 & 11.47 & 62.41 & 0.34 & 9.12 & 1.56 & 12.10 \\
MB & 82.96 & 7.04 & 8.87 & 2.11 & 4.95 & 4.28 & 72.75 \\
Sorghum & 89.46 & 10.54 & 17.01 & 3.56 & 4.14 & 3.39 & 61.36
\end{tabular}

Note: $\mathrm{GNC}=$ groundnut cake, $\mathrm{FM}=$ fish meal, $\mathrm{MB}=$ maize bran, $\mathrm{DM}=$ dry matter, $\mathrm{MC}=$ moisture content, $\mathrm{CP}=\mathrm{crude}$ protein, $\mathrm{CF}=$ crude fibre, $\mathrm{EE}=$ ether extract, $\mathrm{NFE}=$ nitrogen free extract.

Table 4. Proximate composition of the experimental diet

\begin{tabular}{ll}
\hline Parameters & Percentage (\%) \\
\hline Crude protein & 44.49 \\
Moisture content & 8.56 \\
Crude fibre & 6.78 \\
Crude fat & 10.59 \\
Total ash & 4.16 \\
Nitrogen free extract (NFE) & 25.42 \\
\hline
\end{tabular}


Table 5. Concentration of TPH in water (mg.L-1) measured during the experimental periods of 12 weeks.

\begin{tabular}{|c|c|c|c|c|c|c|}
\hline \multicolumn{6}{|c|}{ Treatments } & \multirow{2}{*}{$\begin{array}{l}\mathrm{P}- \\
\text { values }\end{array}$} \\
\hline Weeks & TRT1 & TRT2 & TRT3 & TRT4 & TRT5 & \\
\hline 0 & $0.44 \pm 0.14$ & $0.32 \pm 0.02$ & $0.29 \pm 0.02$ & $0.17 \pm 0.03$ & ND & 0.012 \\
\hline 2 & $0.57 \pm 0.11$ & $0.39 \pm 0.23$ & $0.16 \pm 0.04$ & $0.18 \pm 0.08$ & ND & 0.004 \\
\hline 4 & $0.37 \pm 0.09$ & $0.16 \pm 0.04$ & $0.31 \pm 0.01$ & $0.09 \pm 0.02$ & ND & 0.003 \\
\hline 6 & $0.50 \pm 0.24$ & $0.29 \pm 0.39$ & $0.27 \pm 0.02$ & $0.18 \pm 0.10$ & ND & 0.063 \\
\hline 8 & $0.36 \pm 0.06$ & $0.35 \pm 0.05$ & $0.13 \pm 0.03$ & $0.14 \pm 0.05$ & ND & 0.000 \\
\hline 10 & $0.40 \pm 0.13$ & $0.43 \pm 0.39$ & $0.14 \pm 0.03$ & $0.18 \pm 0.11$ & ND & 0.059 \\
\hline 12 & $0.67 \pm 0.03$ & $0.30 \pm 0.34$ & $0.13 \pm 0.03$ & $0.26 \pm 0.01$ & ND & 0.009 \\
\hline
\end{tabular}

Note: $\mathrm{ND}=$ not detected; TPH=total petroleum hydrocarbon while TRT1 - TRT5=treatments 1 - 5

Table 6. Concentration of TPH in Clarias gariepinus (mg.kg-1) measured during the 12 weeks

\begin{tabular}{lllllll}
\hline \multicolumn{3}{c}{ Treatments } & & $\begin{array}{l}\text { P - } \\
\text { values }\end{array}$ \\
\hline Weeks & TRT1 & TRT2 & TRT3 & TRT4 & TRT5 & \\
\hline 0 & $5.01 \pm 0.66$ & $3.01 \pm 0.17$ & $0.89 \pm 0.01$ & $0.40 \pm 0.23$ & ND & 0.00 \\
2 & $0.39 \pm 0.09$ & $0.45 \pm 0.32$ & $0.56 \pm 0.36$ & $0.22 \pm 0.14$ & ND & 0.265 \\
4 & $0.37 \pm 0.06$ & $0.24 \pm 0.14$ & $0.27 \pm 0.21$ & $0.20 \pm 0.16$ & ND & 0.232 \\
6 & $0.46 \pm 0.04$ & $0.33 \pm 0.14$ & $0.35 \pm 0.01$ & $0.21 \pm 0.16$ & ND & 0.310 \\
8 & $0.58 \pm 0.10$ & $0.42 \pm 0.05$ & $0.25 \pm 0.15$ & $0.18 \pm 0.07$ & ND & 0.008 \\
10 & $0.82 \pm 0.08$ & $0.72 \pm 0.10$ & $0.55 \pm 0.16$ & $0.39 \pm 0.16$ & ND & 0.005 \\
12 & $0.93 \pm 0.05$ & $0.37 \pm 0.11$ & $0.43 \pm 0.06$ & $0.43 \pm 0.08$ & ND & 0.000 \\
\hline
\end{tabular}

Note: $\mathrm{ND}=$ not detected; $\mathrm{TPH}=$ total petroleum hydrocarbon while TRT1 - TRT5=treatments $1-5$.

Table 7. Concentration of heavy metals in water (mg.L-1) measured for the 12 weeks bioassay

\begin{tabular}{|c|c|c|c|c|c|c|c|c|}
\hline \multirow{2}{*}{$\begin{array}{l}\text { Heavy } \\
\text { metals }\end{array}$} & \multicolumn{5}{|c|}{ Treatments } & \multirow[b]{2}{*}{$\begin{array}{l}P \text { - } \\
\text { values }\end{array}$} & \multirow{2}{*}{$\begin{array}{l}\text { NIS } \\
(2007)\end{array}$} & \multirow[b]{2}{*}{$\begin{array}{l}\text { WHO } \\
(2004)\end{array}$} \\
\hline & TRT1 & TRT2 & TRT3 & TRT4 & $\begin{array}{l}\text { TRT5 } \\
\text { (control) }\end{array}$ & & & \\
\hline $\mathrm{Cu}$ & $0.17 \pm 0.09$ & $0.26 \pm 0.24$ & $0.10 \pm 0.01$ & $0.32 \pm 0.31$ & ND & 0.053 & 1.00 & 2.00 \\
\hline $\mathrm{Pb}$ & $0.21 \pm 0.16$ & $0.10 \pm 0.01$ & $0.10 \pm 0.00$ & $0.10 \pm 0.00$ & ND & 0.058 & 0.01 & 0.20 \\
\hline $\mathrm{Ni}$ & $0.11 \pm 0.01$ & $0.09 \pm 0.00$ & $0.11 \pm 0.00$ & $0.10 \pm 0.00$ & ND & $0.000 *$ & 0.02 & 0.02 \\
\hline $\mathrm{Cd}$ & $0.19 \pm 0.14$ & $0.10 \pm 0.00$ & $0.09 \pm 0.00$ & $0.10 \pm 0.01$ & ND & $0.042 *$ & 0.003 & 0.003 \\
\hline $\mathrm{Fe}$ & $0.32 \pm 0.30$ & $0.10 \pm 0.00$ & $0.10 \pm 0.01$ & $0.10 \pm 0.01$ & ND & 0.090 & 0.03 & 0.30 \\
\hline $\mathrm{Zn}$ & $0.26 \pm 0.23$ & $0.10 \pm 0.00$ & $0.10 \pm 0.00$ & $0.10 \pm 0.01$ & ND & 0.074 & 3.00 & 3.00 \\
\hline $\mathrm{Mn}$ & $0.14 \pm 0.04$ & $0.09 \pm 0.00$ & $0.09 \pm 0.00$ & $0.10 \pm 0.01$ & ND & $0.002 *$ & 0.20 & 0.40 \\
\hline $\mathrm{Cr}$ & $0.66 \pm 0.53$ & $0.05 \pm 0.02$ & $0.04 \pm 0.02$ & $0.07 \pm 0.02$ & ND & 0.067 & 0.05 & 0.05 \\
\hline
\end{tabular}


Table 8. Concentration of heavy metals in C. gariepinus (mg. $\left.\mathrm{kg}^{-1}\right)$ measured during the weeks bioassay

\begin{tabular}{|c|c|c|c|c|c|c|c|c|}
\hline \multirow{2}{*}{$\begin{array}{l}\text { Heavy } \\
\text { metals }\end{array}$} & \multicolumn{5}{|c|}{ Treatments } & \multirow[b]{2}{*}{$\begin{array}{l}\mathrm{P}- \\
\text { values }\end{array}$} & \multirow[b]{2}{*}{$\begin{array}{l}\text { NIS } \\
(2007)\end{array}$} & \multirow[b]{2}{*}{$\begin{array}{l}\text { WHO } \\
(2004)\end{array}$} \\
\hline & TRT1 & TRT2 & TRT3 & TRT4 & $\begin{array}{l}\text { TRT5 } \\
\text { (control) }\end{array}$ & & & \\
\hline $\mathrm{Cu}$ & $0.64 \pm 0.13$ & $0.06 \pm 0.02$ & $0.03 \pm 0.02$ & $0.06 \pm 0.02$ & ND & 0.160 & 1.00 & 2.00 \\
\hline $\mathrm{Pb}$ & $0.27 \pm 0.26$ & $0.05 \pm 0.04$ & $0.04 \pm 0.02$ & $0.06 \pm 0.04$ & ND & 0.111 & 0.01 & 0.20 \\
\hline $\mathrm{Ni}$ & $0.08 \pm 0.01$ & $0.08 \pm 0.01$ & $0.05 \pm 0.02$ & $0.03 \pm 0.02$ & ND & $0.011 *$ & 0.02 & 0.02 \\
\hline $\mathrm{Cd}$ & $0.04 \pm 0.02$ & $0.05 \pm 0.03$ & $0.04 \pm 0.01$ & $0.06 \pm 0.04$ & ND & 0.254 & 0.003 & 0.003 \\
\hline $\mathrm{Fe}$ & $0.05 \pm 0.03$ & $0.05 \pm 0.03$ & $0.06 \pm 0.02$ & $0.07 \pm 0.03$ & ND & 0.214 & 0.03 & 0.30 \\
\hline $\mathrm{Zn}$ & $0.06 \pm 0.04$ & $0.07 \pm 0.04$ & $0.05 \pm 0.05$ & $0.05 \pm 0.05$ & ND & 0.172 & 3.00 & 3.00 \\
\hline $\mathrm{Mn}$ & $0.08 \pm 0.04$ & $0.06 \pm 0.01$ & $0.06 \pm 0.02$ & $0.04 \pm 0.01$ & ND & $0.015 *$ & 0.20 & 0.40 \\
\hline $\mathrm{Cr}$ & $0.09 \pm 0.00$ & $0.08 \pm 0.02$ & $0.05 \pm 0.02$ & $0.05 \pm 0.02$ & ND & $0.018 *$ & 0.05 & 0.05 \\
\hline
\end{tabular}

Note: ${ }^{*}=$ there is a significant difference among the means across the treatments, ND=not detected, TRT1 TRT5=treatments $1-5$, NIS=Nigeria industrial standard, WHO=World health organisation.

Table 9. Basic growth parameters of Clarias gariepinus measured during the12 weeks experimental periods

\begin{tabular}{|c|c|c|c|c|c|}
\hline Parameters & TRT1 & TRT2 & TRT3 & TRT4 & TRT5 \\
\hline \% Hatchability & $39.74 \pm 2.06^{c}$ & $43.62 \pm 0.16 c$ & $50.09 \pm 4.98 \mathrm{bc}$ & $62.45 \pm 6.23^{b}$ & $71.13 \pm 0.37^{a}$ \\
\hline MBWG (g) & $0.19 \pm 0.02^{b c}$ & $0.33 \pm 0.10^{b}$ & $1.96 \pm 0.09 b c$ & $3.41 \pm 0.14^{b}$ & $6.62 \pm 0.17 a$ \\
\hline AGR (g.day-1) & $4.22 \pm 0.01^{c}$ & $7.56 \pm 0.08^{b}$ & $9.41 \pm 0.03^{b}$ & $12.85 \pm 0.32^{b}$ & $18.74 \pm 0.04^{a}$ \\
\hline SGR (\%) & $0.89 \pm 0.31^{b}$ & $1.02 \pm 0.01^{b}$ & $2.12 \pm 0.12^{b}$ & $4.56 \pm 0.07 a$ & $6.29 \pm 0.75^{a}$ \\
\hline \% Survival & $34.17 \pm 8.09^{b}$ & $38.33 \pm 0.56^{b}$ & $37.50 \pm 1.81^{b}$ & $44.17 \pm 2.98^{b}$ & $63.33 \pm 1.45^{a}$ \\
\hline AWaH (g) & $13.92 \pm 8.27^{c}$ & $16.99 \pm 11.47^{c}$ & $24.52 \pm 14.54^{b}$ & $29.85 \pm 18.11^{b}$ & $37.05 \pm 2.79 a$ \\
\hline FCR & $3.92 \pm 0.08^{a}$ & $3.01 \pm 1.04 a$ & $2.25 \pm 0.41^{a}$ & $2.41 \pm 0.67^{a}$ & $1.19 \pm 0.43^{b}$ \\
\hline Feed efficiency (\%) & $25.51 \pm 0.98^{c}$ & $33.22 \pm 5.23^{c}$ & $44.44 \pm 7.23^{b}$ & $41.49 \pm 1.08^{b}$ & $84.03 \pm 0.19 a$ \\
\hline $\begin{array}{l}\text { Fish yield } \\
\left(\text { Kg.0.033 m².90 }^{2} .00\right. \\
\left.\text { days }^{-1}\right)\end{array}$ & $0.04 \pm 0.02^{b}$ & $0.05 \pm 0.03^{b c}$ & $0.04 \pm 0.01^{c}$ & $0.08 \pm 0.02^{b}$ & $0.10 \pm 0.01^{a}$ \\
\hline
\end{tabular}


Table 10. Haematological parameters of Clarias gariepinus measured during the 12 weeks experimental periods

\begin{tabular}{|c|c|c|c|c|c|c|}
\hline \multirow[b]{2}{*}{ Parameters } & \multicolumn{5}{|c|}{ Treatments } & \multirow[b]{2}{*}{$\begin{array}{l}\mathrm{P}- \\
\text { values }\end{array}$} \\
\hline & 1 & 2 & 3 & 4 & 5 & \\
\hline PCV (\%) & $20.62 \pm 3.37$ & $29.02 \pm 0.30$ & $43.55 \pm 0.78$ & $42.12 \pm 4.09$ & $49.37 \pm 3.07$ & 0.001 \\
\hline $\mathrm{Hb}(\mathrm{g} / \mathrm{dL})$ & $4.31 \pm 0.98$ & $1.82 \pm 0.40$ & $5.44 \pm 0.80$ & $5.80 \pm 0.42$ & $13.61 \pm 8.27$ & 0.000 \\
\hline $\begin{array}{l}\operatorname{RBC}\left(10^{6}\right. \\
\left.\mathrm{mm}^{-3}\right)\end{array}$ & $2.49 \pm 0.72$ & $2.18 \pm 0.04$ & $3.15 \pm 0.07$ & $3.96 \pm 0.23$ & $9.07 \pm 1.50$ & 0.001 \\
\hline $\begin{array}{l}\text { WBC }\left(10^{3}\right. \\
\left.\mathrm{mm}^{-3}\right)\end{array}$ & $2.12 \pm 1.24$ & $2.56 \pm 0.35$ & $3.72 \pm 0.40$ & $4.60 \pm 0.85$ & $10.22 \pm 1.72$ & 0.003 \\
\hline $\operatorname{MCV}(\mathrm{fL})$ & $2.16 \pm 1.19$ & $2.42 \pm 0.02$ & $3.56 \pm 0.62$ & $3.53 \pm 0.47$ & $6.33 \pm 0.61$ & 0.010 \\
\hline $\mathrm{MCH}(\mathrm{Pg})$ & $2.12 \pm 1.67$ & $2.61 \pm 0.72$ & $4.51 \pm 1.15$ & $4.77 \pm 2.35$ & $8.53 \pm 1.74$ & $0.094 *$ \\
\hline $\begin{array}{l}\mathrm{MCHC} \text { (g.dL- } \\
\text { 1) }\end{array}$ & $6.12 \pm 4.41$ & $17.52 \pm 4.36$ & $28.33 \pm 9.44$ & $37.32 \pm 4.12$ & $48.09 \pm 12.57$ & 0.017 \\
\hline Neut (\%) & $3.26 \pm 1.0$ & $15.23 \pm 8.17$ & $35.16 \pm 13.92$ & $41.14 \pm 2.07$ & $58.69 \pm 11.72$ & 0.009 \\
\hline Lym (\%) & $2.12 \pm 1.25$ & $17.26 \pm 4.44$ & $27.83 \pm 10.15$ & $34.54 \pm 0.79$ & $44.4 \pm 6.81$ & 0.001 \\
\hline Mon (\%) & $0.25 \pm 0.22$ & $0.17 \pm 0.05$ & $0.57 \pm 0.04$ & $0.42 \pm 0.17$ & $4.10 \pm 1.41$ & 0.007 \\
\hline Eos (\%) & $0.78 \pm 0.18$ & $0.17 \pm 0.09$ & $1.50 \pm 0.56$ & $1.68 \pm 1.22$ & $4.23 \pm 2.02$ & $0.078 *$ \\
\hline Baso (\%) & $1.66 \pm 0.08$ & $1.39 \pm 0.02$ & $1.78 \pm 0.03$ & $1.74 \pm 0.34$ & $0.14 \pm 0.72$ & 0.009 \\
\hline
\end{tabular}

Note: ${ }^{*}=$ No significant difference; $\mathrm{PCV}=$ packed cell volume, $\mathrm{Hb}=$ haemoglobin concentration, $\mathrm{RBC}=$ red blood cells, $\mathrm{WBC}=$ white blood cells, $\mathrm{MCV}=$ mean cell volume, $\mathrm{MCH}=$ mean cell haemoglobin, $\mathrm{MCHC}=$ mean cell haemoglobin concentration, Neut=neutrophil, Lym=lymphocytes, Mon=monocytes, Eos=eosinophils while Baso=basophils.

Table 11. Serum biochemical indices of Clarias gariepinus measured during the 12 weeks experimental periods

\begin{tabular}{lllllll}
\hline \multirow{2}{*}{ Parameters } & \multicolumn{7}{c}{ Treatments } \\
\cline { 2 - 6 } & TRT 1 & TRT 2 & TRT 3 & TRT 4 & TRT 5 & $\begin{array}{l}\text { P - } \\
\text { values }\end{array}$ \\
\hline Glucose (g.dL-1) & $41.44 \pm 2.50$ & $27.78 \pm 5.53$ & $39.85 \pm 3.73$ & $16.77 \pm 5.98$ & $17.67 \pm 13.19$ & 0.048 \\
Urea (mg.dL-1) & $29.22 \pm 6.77$ & $18.83 \pm 1.66$ & $13.00 \pm 4.24$ & $9.55 \pm 5.01$ & $6.50 \pm 2.12$ & 0.019 \\
Na (meq.L-1) & $52.54 \pm 26.21$ & $44.49 \pm 0.69$ & $53.45 \pm 0.78$ & $42.69 \pm 5.21$ & $43.93 \pm 2.72$ & 0.824 \\
PP (g.dL-1) & $5.65 \pm 2.33$ & $2.09 \pm 0.12$ & $1.99 \pm 1.40$ & $3.27 \pm 1.03$ & $2.72 \pm 0.40$ & 0.630 \\
Albumin (g.dL-1) & $3.57 \pm 2.03$ & $2.33 \pm 0.95$ & $2.81 \pm 1.69$ & $2.03 \pm 0.04$ & $1.26 \pm 0.40$ & 0.90 \\
& $2.51 \pm 0.71$ & $1.52 \pm 0.69$ & $1.04 \pm 0.05$ & $1.24 \pm 0.34$ & $0.83 \pm 0.22$ & 0.518 \\
Globulin (g.dL-1) & $1.42 \pm 0.11$ & $1.53 \pm 0.28$ & $2.70 \pm 0.21$ & $1.64 \pm 0.97$ & $1.52 \pm 0.45$ & 1.74 \\
Alb-Glob ratio & $32.22 \pm 3.81$ & $20.88 \pm 18.55$ & $12.37 \pm 10.79$ & $10.27 \pm 6.69$ & $6.99 \pm 4.26$ & 0.062 \\
ALP (IU.L-1) & $24.23 \pm 9.58$ & $20.94 \pm 15.65$ & $9.71 \pm 3.24$ & $7.12 \pm 4.07$ & $6.23 \pm 3.92$ & 0.026 \\
ALT (IU.L-1) & $2.00 \pm 0.00$ & $2.03 \pm 1.38$ & $1.30 \pm 0.42$ & $2.10 \pm 1.27$ & $1.58 \pm 0.59$ & 0.870 \\
K (mmol.L-1) & $38.50 \pm 24.75$ & $17.38 \pm 9.02$ & $11.14 \pm 3.03$ & $6.72 \pm 2.43$ & $3.38 \pm 0.54$ & 0.015 \\
Creatinine & $40.44 \pm 7.57$ & $21.88 \pm 17.14$ & $17.27 \pm 12.35$ & $6.88 \pm 0.17$ & $4.99 \pm 0.01$ & 0.045 \\
(mg.dL-1) & AST (IU.L-1) & &
\end{tabular}

Note: $\mathrm{GLU}=$ glucose, $\mathrm{Na}=$ sodium, $\mathrm{PP}=$ plasma protein, $\mathrm{ALB}=$ albumin, GLOB=globulin, $\mathrm{ALP}=$ aminoalanine

phosphatase, $\mathrm{ALT}=$ alanine transaminase, $\mathrm{K}=$ potassium, $\mathrm{CRE}=$ creatinine, $\mathrm{AST}=$ aspartate transaminase. 

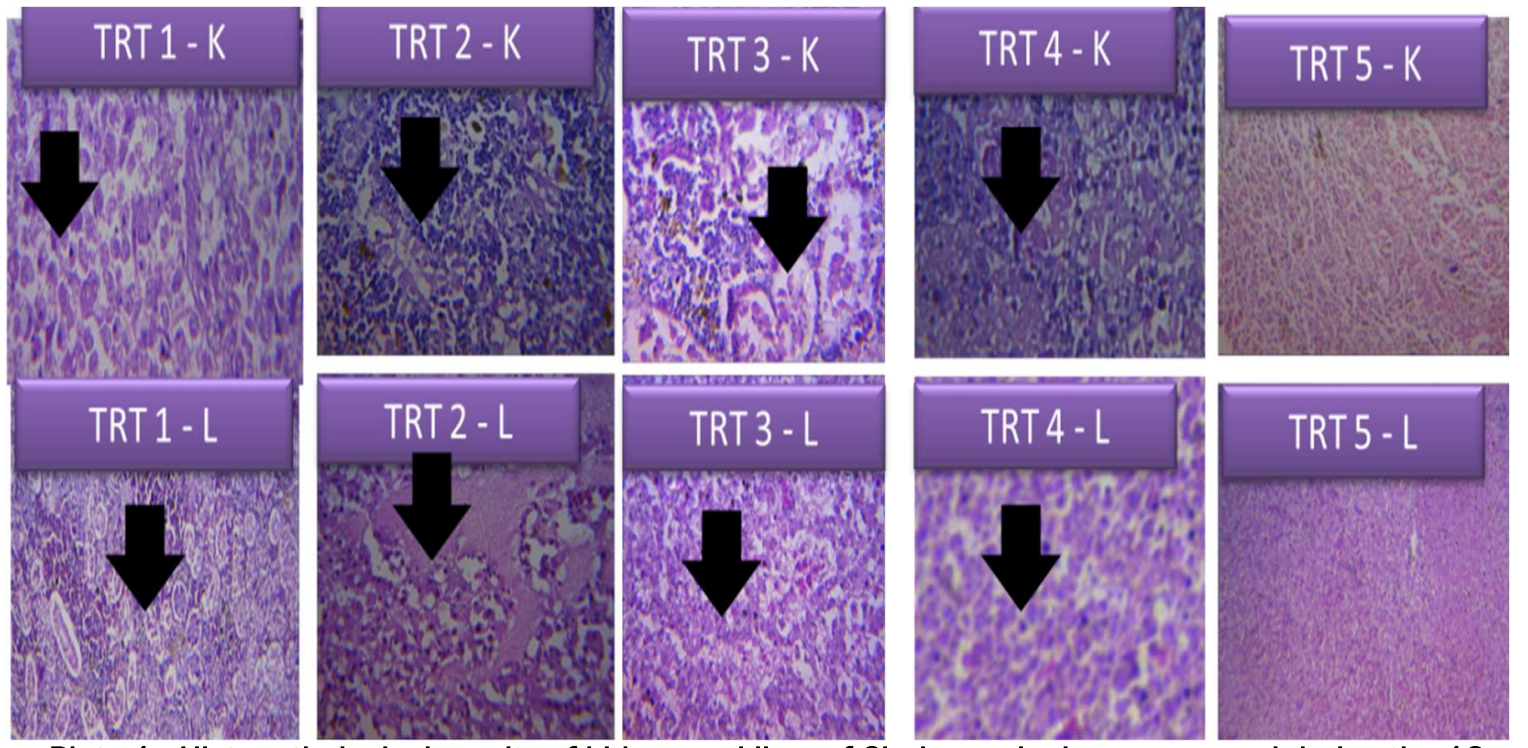

Plate 1. Histopathological results of kidney and liver of Clarias gariepinus measured during the 12 weeks experimental periods using water of Gbalegbe River from the effluents discharge point.

\section{Magnification $=x 400$}

TRT $=$ treatment, $\mathrm{L}=$ Liver and $\mathrm{K}=\mathrm{Kidney}$. TRT $5-\mathrm{K}$ and TRT $5-\mathrm{L}=\mathrm{Kidney}$ and liver of control fish with normal structural compositions. TRT $1-K$ to TRT $4-K$ showed severe diffused tubular degeneration with many tubules having protein cast in their luminar. There was also an extensive renal congestion at the cortex. TRT1 - L showed severe portal congestion with very mild diffused hydropic degeneration of hepatocytes. TRT2 - L showed melanomacrophage centres which is very prominent and expanded. TRT3 \& TRT4 showed mild portal congestion with mild diffused vacuolation of hepatocytes.

\section{DISCUSSION}

The levels of Copper recorded in the fish and water samples were less than the allowable limits of NIS, (2007) but higher than the recommended limits for Copper in water $\left(0.05 \mathrm{mg}^{-\mathrm{L}^{-1}}\right)$ and fish flesh (2.54 mg.L-1) respectively (WHO, 2004). Concentration of lead recorded was within the acceptable limit except at TRT 1 were it was marginally higher. This can be attributed to the fact that the water in TRT 1 was the raw water collected from the most polluted station and used without dilution. Ewutanure and Olaifa, 2018a; Olowu et al. 2012) reported that lead is known to inhibit active transport mechanisms, connected with adenosine triphosphate, reduced cellular oxidation, reduction reactions and inhibition of protein synthesis. It inhibits the impulse conductivity by suppressing the activities of monoamine oxidase and acetylcholine esterase leading to pathological changes in tissues, organs of developing embryo and larval of fish (Olowu, et al. 2010).

The results showed that the lowest growth parameters examined were noted in TRT 1 and gradually increasing as the effluent's concentrations decreases. The best growth parameters were recorded in treatment 5 (control). Olomukoro and Azubuike, (2010) observed that suppressed growth could be due to inadequate feeding of an experimental fish because of the presence of the contaminants contained in the effluent. 
The increase in the SGR, FE and the decrease in FCR from TRT 1 to TRT 5 showed that the feeding and growth rate of $\mathrm{C}$. gariepinus were negatively affected by the presence of TPH and heavy metal concentrations present in the water. It has been reported that cadmium concentration obtained in fish is noteworthy and it is believed to contributes to pulmonary disease, acute kidney and liver damage, reduction in glucose tolerance and death (Ewutanure and Olaifa, 2018c). High level accumulation of cadmium in liver may be associated with its strong binding potential with cystine residues of metallothionein (Olomukoro and Oronsaye, 2009).

Iron concentration recorded in water was marginally higher than recommended standard in TRT 1 but was less than acceptable limits in fish. Iron is an important composition of haemoglobin essentially for the transportation of oxygen and prevention of anaemic condition (NIS, 2007). Manganese concentration recorded in both water and fish samples were lower than the results obtained in Tarkwa Bay, Nigeria (Lawal - Are and Babaranti, 2014). Manganese helps in the formation of bones, healthy functioning of the nervous system and reproduction processes (WHO, 2004). The migration of heavy metals in fish takes place in the blood streams where the ions are bonded to proteins and in contact with the tissues of fish where they are bioaccumulated to higher levels (Olawusi - Peters et al. 2014). Lead, cadmium and copper are harmful to aquatic organisms even at micro-concentrations and are being reported as hazardous pollutants capable of accumulating along the aquatic food chain with deleterious effects on fish and man (Ololade et al. 2008).

The impacts of pollutants have been known to cause reduction in fertility, reproductive abnormalities and alteration in the functions of the immune systems (NIS, 2007). Cadmium is capable of accumulating in freshwater and marine biota thereby causing rapid genetic changes negatively (Lawal - Are and Babaranti, 2014). The toxic effects of these metals could be attributed to their ability to cause oxidative damage to living tissues which include enzyme inactivation, DNA damage, lipid peroxidation and oxidation of protein sulphydryl groups. Heavy metal accumulation in fish could cause liver and kidney problems as well as cardiovascular diseases and anaemic conditions (Ololade et al. 2008).

Chronic exposure to aquatic contaminants have been reported to induce morphological, histological and biochemical alterations in the tissues of fishes (Bukola et al. 2015).

Serum biochemical analyses revealed higher levels of ALP, ALT and AST when compared with control. This could be noted as an indication of liver damage which may be attributed to the presence of crude oil and heavy metal concentrations in water and C. gariepinus above the recommended limits (Subhendu, 2000). The liver was greatly affected because it is the organ responsible for the breakdown of toxicants while the kidney was the next most damaged being the organ responsible for the excretion of urine and other nitrogenous compounds from the body (Olawusi - Peters et al. 2014).

The TRT1 - L showed severe portal congestion with very mild diffused hydropic degeneration of hepatocytes; very prominent and expanded melanomacrophage centres (TRT2 - L); mild portal congestion with diffused vacuolation of hepatocytes (TRT3 and TRT4). These findings justified the fact that the liver is considered the organ for detoxification, excretion and binding proteins such as metallothionein (Hinton and Lauren, 1990; Olawusi - Peters et al. 2014). The metalbinding proteins, present in the nuclei of hepatocytes suggested increase in the cell damages. 
Similar results were reported by NIS, (2007). TRT 1 - K to TRT 4 - K showed severe diffused tubular degeneration with many tubules having protein cast in their luminar. There was also an extensive renal congestion at the cortex.

\section{CONCLUSION AND RECOMMENDATIONS}

As a result of the bio-accumulated contaminants, fish species suffers haematological and serum bio-chemical changes, histopathological alterations with consequent inhibition of metabolic processes, reduction in fertility and survival (Ololade et al. 2008). High concentrations of heavy metals and TPH found in fish may be associated with the storage role the liver and the kidney played (Olowu et al. 2010). Results of this study indicated that heavy metal and TPH contamination affect the growth performance and the reproductive process of $\mathrm{C}$. gariepinus in Gbalegbe River. Hence, there should be constant monitoring of Gbalegbe River so as to detects any change that is capable of causing negative effects in its aquatic biota.

\section{REFERENCES}

1. Abel, O.A. and Afolabi, O., (2007). Estimating the quantity of solid waste generation in Oyo, Nigeria. Waste Management and Research 25: 371-379.

2. Abel, O.A., (2009). An analysis of solid waste generation in a traditional African city: the example of Ogbomoso, Nigeria. Environment and Urbanization 19: 527-537.

3. Akintola, S.L., Kumolu, J.C.A., Fakoya, K.A. and Asamu, S.O., (2009). Developments and growth in the aquaculture industry of Nigeria. Africa Journal of Management and Development 21-25.

4. Brown, M.E., (1957). Experimental studies on growth. The Physiology of fishes. 1: 360 400.

5. Bukola, D., Zaid, A., Olalekan, E.I. and Falilu, A., (2015). Consequences of Anthropogenic Activities on Fish and the Aquatic Environment. Poult Fish Wildlife Sci 3: 138. doi:10.4172/2375-446X.1000138

6. Edokpayi, C.A., Nkwoji, J.A., (2000). Annual changes in the physico-chemical and macrobenthic invertebrate characteristics of the Lagos lagoon sewage dump site at Iddo, Southern Nigeria. Ecol Environ Cons 13: 13-18.

7. Ewutanure, S.J. \& Olaifa, F.E. (2021): Spatial and Temporal Fluctuations of Physico Chemical Parameters, Nutrients and Primary Productivity of Gbalegbe River, Delta State, Nigeria Proceedings of the 28th iSTEAMS Intertertiary Multidisciplinary Conference. American International University West Africa, The GambiaSeries 28, Vol 3 October, 2021. Pp 137-1 www.isteams.net/gambia2021. DOI - https://doi.org/ 10.22624/AIMS/iSTEAMS-2021/V28N3P11.

8. Ewutanure, S.J. and Olaifa, Flora. E. (2018a): Phytoplankton Species Composition, Distribution, Abundance and Diversity in Gbalegbe River, Delta State, Nigeria. Proceedings of $6^{\text {th }}$ NSCB Biodiversity Conference; Uniuyo, $164-170$.

9. Ewutanure, S. J. and Olaifa, F. E. (2018b): Heavy metal concentrations in water and sediment of Gbalegbe River, Delta State, Nigeria. The 2nd SETAC Central/West Africa Regional Conference, Environmental sustainability and pollution control through science. Book of Abstract, 4 Pp. 
10. Ewutanure, S. J. and Olaifa, F. E. (2018c): Biochemical changes in Clarias gariepinus juveniles exposed to sublethal concentrations of lead and zinc chloride in water with and without bracken fern (Pteridium aquilinum) The 2nd SETAC Central/West Africa Regional Conference, Environmental sustainability and pollution control through science. Book of Abstract, 4 Pp.Federal Environmental Protection Agency (FEPA), 1991. Guidelines and Standards for Environmental Pollution Control in Nigeria. National Environmental Standards-Parts 2 and 3, Government Press, Lagos. 1 - 238.

11. Food and Agricultural Organisation (FAO), (2009). Fish eggs production and management procedure. Manual of fish breeding. P. $1-23$.

12. Fleck, H., (1976). Introduction to nutrition, $3^{\text {rd }}$ Edition. Macmillian, New York, USA. p. 7 $-219$.

13. Hinton, D.E. and Laurén, D.J., (1990). Liver structural alterations accompanying chronic toxicity in fishes. Potential biomarkers of exposure. In: Biomarkers of Environmental Contamination 17-57.

14. Ishwata, N., (1969). Ecological studies on the feeding of fishes: Frequency of feeding and growth. Bulletin Jan. Soci. Fish. 35: 985 - 989.

15. Lawal - Are, A.O. and Babaranti, O.A., (2014). Heavy metal concentrations in Pseudotolithus typhus, Portunus validus, water and sediment from Takwa Bay, Nigeria. Nigeria Journal of Fisheries. 11 (1 and 2): 733 - 744.

16. Nigeria Industrial Standards (NIS). 2007. Nigeria standard for drinking water quality ICS 12.060.20, Approved by standard organization of Nigeria (SON) governing council Lagos and

Abuja, Nigeria.http//www.unicef.org/Nigeria/ng_publication_nigeria_standard_for_drinking water.

17. Nkwoji, J.A., Yakub, A., Ajani, G.E., Balogun, K.J. and Renner, K.O., (2010). Seasonal variations in the water chemistry and benthic macroinvertebrates of a South Western Lagoon, Lagos, Nigeria. J Am Sci 6: 85-92.

18. Olawusi-Peters, O.O., Ayo-Olalusi, C.I. and Adeyemi, T.V. 2014. Bioaccumulation of some trace element ( $\mathrm{Zn}, \mathrm{Fe}, \mathrm{Pb}$ and $\mathrm{Cu}$ ) in the gills and tissues of Clarias gariepinus and Oreochromis niloticus in River Ogbese, Ondo State, Nigeria. Journal of Environmental Chemistry and Ecotoxicology 6.2:13 - 19.

19. Ololade, A., Lajide, L., Amoo, A. and Oladoja, A. 2008. Investigation of heavy metals contamination of edible marine sea food. African Journal of Pure and Applied Chemistry 2.12: $121-131$.

20. Olomukoro, J. O. and Oronsaye, C. 2009. The Plankton Studies of the Gulf of Guinea, Nigeria. Bioscience Resources and Communication 7.2:23 - 34.

21. Olomukoro, J.O. and Azubuike, C.N. 2010. Heavy metals and macro invertebrate communities in bottom sediment of Ekpan Creek, Warri, Nigeria. Journal of Biological sciences 2.1: 1-8.

22. Olowu, R.A., C.T. Onwordi, A.A. Denloye, M.O Osundiya, N.O. Adebayo, M.S. Owolabi, O.O. Tovide, B.A. Moronkola, O.A. Omoyeni, Ajuwon, O. R. 2012. Heavy Metals in Oreochromis niloticus (Linnaeus, 1758) (Persiformes: Cichlidae), Ictalurus punctanus (Rafinesque, 1818) (Suliriformes: Ictaluridae) and Bottom Sediments from Lagos Lagoon Proximal to Egbin Power Plant, ljede, Ikorodu, Lagos Nigeria". Research Journal of Environment and Earth Sciences 4.3: 237 - 243.

23. Olowu, R.A., O.O.; Ayejuyo, G.O. Adewuyi, A.O Babatunde, I.A. Adejoro, A.A.B, Denloye, and Ogundajo, A. L. 2010. Heavy metals in fish tissue, water, sediment from Epe and Badagry lagoons Nigeria. E-Journal of Chemistry 7.1: 215 - 221. 
24. Omeje, V.O., Musa, Y.M., Abubakar, I., Wonah, C., Binyotubo, O., Ekundayo, T. and Offor, C., (2013). Hatchery management. In: Okaeme, A.N., Jude, C. N., Olufeagba, S.I. and Ilyasu, A., Editors. Introduction to Freshwater Fisheries. National Institute for Freshwater Fisheries Research, Niger State, Nigeria. Publisher: ESPATEK Nigeria Limited. P.47 - 64.

25. Subhendu, D., (2000). Effects of aquatic pollution on fish and fisheries. Pollution-An International problem for fisheries. Can J Fish Aquat Sci 66: 400-480.

26. Valipour, M., (2013a). Estimation of Surface Water Supply Index Using Snow Water Equivalent. Advances in Agriculture, Sciences and Engineering Research 3: 587-602.

27. Valipour, M., (2013b). Use of surface water supply index to assessing of water resources management in colorado and oregon, US. Advances in Agriculture, Sciences and Engineering Research 3: 631-640.

28. Valipour, M., Banihabib, M.E., Behbahani, S.M.R., (2012). Monthly Inflow Forecasting Using Autoregressive Artificial Neural Network. Journal of Applied Sciences 12: 21392147.

29. Viadero, R.C., (2005). Factors affecting fish growth and production. Water Encyclopedia. 3:129 - 133.

30. World Health Organisation -WHO, (2004). Guidelines for Drinking Water Quality. $3^{\text {rd }}$ ed. World Health Organization. p.515.

31. Zeiotoun, I.H., Jack, I., Halver, J.F., Ulray, D.F., (1973). Influence of salinity on protein requirements. J. Fish. Board. Can. 301867 - 1873. 